\title{
Consequences of Covid-19 Pandemic on Hospitality Industry: The Nigeria Experience
}

\author{
Mercy Busayo BELLO ${ }^{1}$, Yekinni Ojo BELLO, PhD. ${ }^{2}$ \\ ${ }^{I}$ Federal Polytechnic Auchi, School of Applied Sciences, Department of Hospitality Management \\ Auchi, Edo State, Nigeria \\ ${ }^{2}$ University of Port Harcourt, Faculty of Management Sciences, Department of Hospitality Management and Tourism Choba, \\ Rivers State, Nigeria
}

\begin{abstract}
Purpose: The current study explores consequences of Covid-19 pandemic on Nigerian hospitality industry.

Research Methodology: The exploratory study reviewed various reports and literature to make insightful inferences.

Findings: The consequences of COVID-19 pandemic on Nigeria hospitality industry include strain on the operations and revenue generation of the industry, steep decline in hotel occupancy rates and low customers' turnover in other hospitality facilities, uncontainable job losses, and mass sales of hospitality business facilities.

Research Implications: By establishing the consequences of Covid-19 pandemic on Nigeria hospitality industry, this study offers an insight for the government of Nigeria to put in place business safety nets such as relief fund for hospitality business owners, and implementation of national tax relief policy to repositioning the sector for national prosperity. Aside, hospitality scholars are expected to shift their research focus to develop solutions for the industry. In addition, hospitality business owners in Nigeria should explore business innovative strategies to reach out to their prospective customers
\end{abstract}

Originality: This paper contributes to the literature that examined the impacts of Covid-19 crises on the hospitality industry in an emerging country with focus on Nigeria.

Keywords: Covid-19, Hospitality industry, Nigeria, Hotel, Restaurant.

\section{INTRODUCTION}

$\mathrm{T}$ The novel Coronavirus pandemic otherwise known as COVID-19 has touched every nook and cranny of the globe with severe impacts on businesses and industry of nations. The causative agent of the outbreak was identified by the World Health Organization (2020) as the severe acute respiratory syndrome coronavirus-2 (SARS-CoV-2), producing the disease named coronavirus disease-2019 (COVID-19). The virus is closely related (96.3\%) to bat coronavirus RaTG13, based on phylogenetic analysis. Human-to-human transmission has been confirmed even from asymptomatic carriers. The disease is characterized by fever, dry cough, and chest pain with pneumonia in severe cases. It is important to state that the first wave of the pandemic was reported to have started in December 2019 at Wuhan, Hubei province, China. By mid-March 2020, 146 countries had been found to have COVID-19 cases (Anderson et al., 2020). As at
April 2020, infection rate had spiked through local transmission with about 2 million confirmed cases in more than 200 countries (European Centre for Disease Prevention and Control, 2020). However, an analysis of the current statistics on COVID-19 infection and death cases globally as of $28^{\text {th }}$ December, 2020 shows that the pandemic has accounted for almost 80 million and 2 million confirmed infection, and deaths cases respectively worldwide (World Health Organization, 2020). Aside, the Covid-19 pandemic has serious effects on national health care system, the food industry, educational industry and travel business among others worldwide.

In the context of Nigeria, the first case of the pandemic was reported on the 27th February, 2020 (Nigeria Center for Disease Control, 2020a). However, analysis of the current infection and death rate of Covid-19 in Nigeria as at $28^{\text {th }}$ December 2020 show that almost 85 thousand confirmed infection cases were reported with 1,264 death rates (The Voice of Africa, 2020; Nigeria Center for Disease Control, 2020b). However, it is important to note that the actual infection rate of the COVID-19 cases remains unknown in Nigeria due to limited testing capacity of the country. In an attempt at controlling the spread of the virus, due to lack of a vaccine for its treatment, the government of Nigeria have resorted to the use of non-pharmaceutical approaches such as social distancing, wearing of face mask, self-quarantines, border closures, and local lockdowns among others. The corresponding effects of these infection spread management strategies led to shutdown of businesses including, the hospitality industry.

It is pertinent to state that the growth rate of Nigeria's hospitality industry in pre Covid-19 era is unprecedented (Bello, 2018). For instance, Hotels been one of the critical industries in the Nigeria hospitality industry attracted significant investment put at over US $\$ 3$ billion in the last three years (PricewaterhouseCoopers, 2017). In terms of contribution to the GDP, hotel industry contributed N1.7billion (\$US 5.5 million) put at $4.8 \%$ to the Nigeria's Gross Domestic Product (GDP) in 2016 (Ekwujuru, 2016; Jumia Travel, 2017). The industry generated 651,000 jobs directly in 2015 put at $1.6 \%$ of total employment in the country and another 1.6\% in 2016 worth N661,000 (Jumia 
Travel, 2017). The Fast-food industry is another key component of the hospitality industry in Nigeria hence, generated annual revenue of N230 billion and taxes in excess of a billion naira to the Nigeria industry (Bukola, 2017). The author further opines that the fast-food industry collectively provided employment for over 500,000 people at the processing and retailing level in Nigeria in 2017. Summarily, the value of the hospitality industry in Nigeria was estimated at N1.4 trillion as at year ending 2019 (LCCI, 2020).

Despite the attractive and stabilized outlook of the Nigeria hospitality industry in the pre Covid-19 era, the emergence and resurgence of this disease were observed to have drastically affected the hospitality industry in Nigeria. It is therefore worthwhile to explore the consequences of the current pandemic on the Nigeria's hospitality industry. It is meaningful to state that some impact studies of Covid-19 in Nigeria context have emerged. Ohia et al (2020) predicts the effect of COVID-19 on the Nigeria's health sector. Jacob et al. (2020) assessed COVID-19 pandemic and Nigeria's higher institutions. Adenomon and Maijamaa (2020) examined the impact of COVID-19 on the Nigerian stock exchange from the 2nd January 2020 to 16th April 2020. Ozili (2020) examined Covid-19 pandemic and economic crisis: the Nigerian experience and structural causes. Olapegba et al. (2020) assessed the knowledge and perceptions of Nigerians about Covid-19. In view of the above studies, it is justifiable to argue that studies that examined the impact of COVID-19 pandemic on Nigeria hospitality industry are scarce. Hence, the focus of this paper is to examine the effects of COVID-19 on the Nigeria's hospitality industry. The analysis in this paper is expected to contribute to the literature that examines the impacts of Covid-19 crises on the hospitality industry in an emerging industry with focus on Nigeria.

\section{LITERATURE REVIEW}

\section{The Concept of Hospitality Industry}

Stereotyped definition of the concept of hospitality industry is not in sight as various definitions of the concept had been offered by definers. Hospitality industry explains all businesses that is responsible for the provision of accommodation, food, drinks, and other supplementary services required by vacationers (Bello and Bello, 2020) including, assurance of reasonable degree of comfort, safety, and above all, adequate relaxations. Robert, et al. (2007) sees hospitality industry as a wide range of businesses such as Hotels, Restaurants, Casinos, Fast Food, and Clubs among others aimed at providing accommodation (i.e., Lodging), and food services as well as other related catering services for people when away from home. Hospitality industry is defined as those internationally impactful industry with wide cross section components of products such as accommodation (Bello and Majebi, 2018), food and beverages (Anthony et al. 2004; Jennifer and Thea, 2013; UNWTO, 2016) and other related services. The index in the above information shows that hospitality industry consists of service-oriented industry that is responsible for the provision of away from home catering services to tourists and travelers.

\section{Hospitality Industry and Infection Diseases}

Hospitality industry globally and pandemics are bidirectionally linked in a cause-and-effect manner (Poulos et al., 2018). The industry is both the main contributor to disease spread and a recipient of its consequences. It is worthy of note that the emergence, re-emergence and spread of epidemics and pandemics such as the 'Spanish' FluFlu of 1918 to 1919, Asian' FluFlu (H2N2) of 1957, the 'Hong Kong' flu of 1968, SARS in 2002 to 2003, 'Bird flu' in 2009, MERS of 2012, and Ebola of 2013-2014 (Wu et al.,2017; Gössling et al., 2020) severely impacted on the hospitality economies globally. The negative impacts of emergence and re-surgency of COVID-19 is not an exception. However, since the scope of the current study focuses on the impacts of the pandemic on the Nigeria's hospitality industry, disease spreading element of the industry in Nigeria context is out of scope of the current study. Hence, the corresponding impacts of the first wave of the Covid-19 pandemic and now the re-surgency of its second wave on the Nigeria's hospitality industry is worth discussing thus the following.

\section{Consequences of Covid-19 Pandemic on the Nigeria Hospitality Industry}

The hospitality industry is dealing with an unprecedented crisis due to the disruption caused by the global COVID-19 pandemic. The challenges created by COVID-19 impacts almost every part of a hospitality business operation, revenue generation, room occupancy levels, staffing plans, and food and beverage provisions among others as further explained below.

\section{Strain on the Operations and Revenue Generation of the Hospitality Industry}

The restrictions enacted and enforced by the government of Nigeria to curb the spread of the Covid-19 virus, especially, the closure of the country's land borders, air-space and sea borders put a strain on the inbound tourists and business travelers who come from outside the country; thus, the border closures and restrictions on public gatherings, deprived hospitality industry such as hotels, restaurants, and aviation catering of their major patrons thus, affecting their revenue generation. For instance, hotel revenue before emergence of Covid-19 in Nigeria expanded at $22.6 \%$ compound annual rate of \$US1.1 billion in 2018 (PricewaterhouseCoopers, 2018). The report further opined that Nigeria's hotel revenue was expected to grow by 507 million dollars by 2020 . However, reports from four of the major listed hotels on the Nigerian Stock Exchange, shows a revenue decline of nearly $90 \%$, due to a fall out of the COVID-19 induced lockdowns (Nairametrics, 2020). The index in the above information shows that Covid-19 has a negative impact on revenue generation capacity of the Nigeria's hospitality industry. 


\section{Steep Decline in Hotel Occupancy}

It is pertinent to report that occupancy rate of all hotels in Nigeria are decreasing as well as wearing a deserted look due to Coronavirus outbreak. The Pre-Covid-19 statistics on hotel occupancies in Nigeria shows that Nigeria's hotel industry accounted for $49.8 \%, 44.7 \%, 43.6 \%, 42.4 \%$, and $42.6 \%$ occupancies in 2014, 2015, 2016, 2017, and 2018 respectively (PricewaterhouseCoopers, 2018). This however implies that demand for hotel accommodation for instance is on the average. However, recent statistics shows that "the slow pick up of international travels, restriction on large gatherings, the switch to virtual meetings, and fear of the virus, has further reduced demand for hotels in Nigeria thus, steeping occupancy levels to its lowest - less than 5\%" (Nairametrics, 2020). The implications of this are that Nigeria hospitality industry is seriously losing demands of her major products hence, the physical capacity of hotel facilities in Nigeria are underutilized.

\section{Job Losses}

It has been reported that hospitality industry in Nigeria is highly labour intensive despite recent trend of technology integration. However, recent realities in the Nigeria's hospitality industry show low patronage of restaurant businesses, major crashes in aviation catering services, closed hotels, and clubs including, event centers due to emergence and resurgence of Covid-19 pandemic. These have resulted in huge losses and large-scale unemployment (ILO, 2020). The dire state of financials capabilities of major hotels listed on the Nigerian stock exchange for instance has forced them to consider massive job cuts, and cost reduction measures in a bid to survive. At the inception of the pandemic, these four major hotels maintained a $100 \%$ salary payment to over 900 employees in March and April, 2020. As at the end of November, 2020, their workforce headcount had reduced by more than $60 \%$.

\section{Mass Sales of Hospitality Business Facilities}

One observed concern occasion by the emergence and resurgence of Covid-19 on the Nigeria's hospitality industry is uncontrol rate of putting up hospitality business premises and facilities for sales in recent time due to bankruptcy. The crushing impact of Coronavirus on the travel industry has a devastating effect on hotels in Nigeria. International travelers also cancelled their travel schedule due to COVID-19. Thousands of small hotels, resorts, motel, travel agencies and other travel related organization have to close their service due to this pandemic. Due to this, Nigeria hotel owners, and restaurant entrepreneurs practically finds it extremely difficult to run and sustain their businesses thus, exerting intense pressure on them to putting up sales advertisement of their properties on the country social media, and television stations seeking for interested buyers. This situation is worsened by poor government support and weak business recovery policy for hospitality business owners.

\section{RESEARCH METHODOLOGY}

The study been an exploratory study, reviewed various reports and previous literature in this domain of study upon which the study made insightful inferences.

\section{FINDINGS}

Major inference that could be drawn from this study is that COVID-19 pandemic has a strong impacts on Nigeria's hospitality industry and consequently on the country's economy at large. Unlike other crises, which allow operators of hospitality businesses in Nigeria to diversify markets, this pandemic has caused abrupt and sudden breaks in all economic activities including, hospitality industry. Severe consequences of the COVID-19 on the Nigeria's hospitality industry as reported in the current study include but not limited to: i. Strain on the operations and revenue generation of the hospitality industry; ii. Steep decline in hotel occupancy rates and low customers' turnover in other hospitality facilities such as restaurants and event centers; iii. Uncontainable job losses, and iv. Mass sales of hospitality business facilities.

\section{DISCUSSION OF FINDINGS}

The discussion of the major findings of this study is as follows:

The study found that hospitality industry in Nigeria is experiencing strains in its operations and revenue generation capacity as a result of COVID-19 pandemic. This result is in agreement with previous study hence, Gossling et al. (2020) reported that hospitality industry always suffer setback in its operations and consequently in its revenue generation due to disasters and crises such as natural disasters, pandemic and other threating emergencies to human life.

In addition, the study also established a steep decline in hotel occupancy rates and low customers' turnover in other hospitality facilities such as restaurants and event centers. This also conform to findings in previous studies hence, Anderson et al. (2000) opined that the novel corona virus pandemic has negatively impacted on the global business including, the hospitality and tourism industry. Gossling et al. (2020) further reported that hospitality and tourism industry is globally experiencing little or no patronage due to nonpharmaceutical procedures such as border closure, selfquarantines, social distancing and business short down put in place to manage the possibility in spike of the Covid-19.

Furthermore, the current study affirmed that uncontainable job losses characterized the Nigeria hospitality industry due to Covid-19 pandemic. This finding conforms to the previous study hence; Gossling et al. (2020) reported that Covid-19 negatively impacted the tourism and hospitality industry globally leading to total shutdown of operations, entirely laidoff of their employees to reduce operational cost.

Mass sales of hospitality business facilities is another finding of this study thus, conform to the previous studies. McKibbin 
and Sidorenko (2006) opined that the impact of epidemic and pandemic on the global business is enormous thus, leading to zero coping capability on the part of the owners and managers. This collaborates the report in Dube et al. (2020) that many hospitality facilities may be unsustainable due to drop to zero sit-in guests for hotels and restaurants as a result of social distancing and other restrictions on movement instituted by the government to curb the spread of Covid-19 hence, making mass sales of these facilities inevitable.

\section{Implication of the Study}

Since hospitality industry in Nigeria has once assumed an important role of economic regeneration and stability given its capabilities in revenue generation, jobs creation, and infrastructure development in the industry recovery experience of Nigeria in previous recession. The findings of this study give a better insight towards the need for the government of Nigeria to put in place feasible business safety nets such as relief fund for hospitality business owners. Implementation of tax relief policy will also make a difference in addressing the acute consequences of the pandemic on the Nigeria's hospitality industry, thereby repositioning the sector for national prosperity. Aside, hospitality scholars are expected to shift their research focus to develop solutions for the industry. Finally, hospitality business owners in Nigeria should put on business innovative cap to reach out to their prospective customers.

\section{REFERENCES}

[1] Adenomon, M. O., and Maijamaa, B. (2020). On the Effects of COVID-19 outbreak on the Nigerian Stock Exchange performance: Evidence from GARCH Models.

[2] Anderson, R. M., Heesterbeek, H., Klinkenberg, D., and Hollingsworth, T. D. (2020). How will country-based mitigation measures influence the course of the COVID-19. The Lancet, 395,(10228), 931-934.

[3] Anthony, B., Marcelo, F., Andrew, H., Sarah, J., Neil, K., David, P., and Kelvin, V. C. (2004). Vission 2020; Forcasting International Student Mpbility; A UK Perspective. England: British Council Department.

[4] Bello, Y. O. (2018). Hospitality and Tourism Economics. Ondo: Grace Excellent Publishers.

[5] Bello, Y. O., and Majebi, E. C. (2018). Lodging Quality Index Approach: Exploring the Relationship Between Service Quality and Customers Satisfaction in Hotel Industry. Journal of Tourism and Heritage Studies, 7, (1), 58-78.

[6] Bello, Y. O., and Bello, M. B. (2020). Introduction to Hospitality and Tourism Management. Ilorin: Ppabulun Global Limited.

[7] Bukola, A. (2017). Trouble Times for the Eatery Business. The Nation, p. 12.

[8] Dube, K., Nhamo, G., and Chikodzi, D. (2020). Current Issues in Tourism COVID-19 cripples' global restaurant and hospitality industry. Current Issues in Tourism, doi.org/10.1080/13683500.2020.1773416.

[9] Ekwujuru, P. (2016). Tourism contributes N1.7bn to GDP in Q3 2016. Lagos: Vangard Newspaper, Sunday 19 November.

[10] European Centre for Disease Prevention and Control (ECDC). (2020). COVID-19 Situation update (4th April, 2020). Retrieved from https://www.ecdc.europa.eu/en/geographical-distribution2019-ncov-cases.

[11] Gossling, S., Scott, S., and Hall, C. M. (2020). Pandemic, tourism and global change: A rapid assessment of COVID-19. Journal of
Sustainable Tourism,

$1-20$.

Doi.org/10.1080/09669582.2020.1758708.

[12] ILO. (2020). COVID-19 and the world of work: Impact and policy responses. Geneve, Switzerland: International Labour Organisation.

[13] Jacob, O. N., Abigeal, I., and Lydia, A. E. (2020). Impact of COVID-19 on the Higher Institutions Development in Nigeria. Electronic Research Journal of Social Sciences and Humanities, 2 , 126-135.

[14] Jennifer, B., and Thea, C. (2013). Travel and Tourism Competitiveness Report: Reducing Barriers to Economic Growth and Job Creation. Geneva: World Economic Forum.

[15] Jumia Travel. (2017). The Hospitality and Tourism Outlook in Nigeria. Lagos: Jumia Travel Nigeria.

[16] McKibbin, W. J., and Sidorenko, A. (2006). Global macroeconomic consequences of pandemic influenza. Sydney, Australia: Lowy Institute for International Policy.

[17] Nairametrics. (2020). Hotels in Nigeria are on the verge of collapse (24th September, 2020). Retrieved from nairametrics.com/2020/09/24/hotels-in-nigeria-are-on-the-vergeof-collapse.

[18] Nigeria Center for Disease Control. (2002a). An update of COVID19 outbreak in Nigeria (14th March, 2020). Retrieved from https://www.thenigerianvoice.com/news/update-on-covid-19-innigeria.html.

[19] Nigeria Center for Disease Control. (2020b). CoronavirusNigeria: Covid 19 Case Update (28th December, 2020). Retrieved from africannew.com/2020/12/29/coronavirus/Nigeria/covid19/caseupd ate.

[20] Ohia, C., Bakarey, A. S., \& Ahmad, T. (2020). COVID-19 and Nigeria: Putting the realities in context. International Journal of Infectious Diseases.

[21] Olapegba, P. O., Ayandele, O., Kolawole, S. O., Oguntayo, R., Gandi, J. C., Dangiwa, A. L. and Iorfa, S. K. (2020). A Preliminary Assessment of Novel Coronavirus (COVID-19) Knowledge and Perceptions in Nigeria.

[22] Ozili, P. K. (2020). Covid-19 pandemic and economic crisis:The Nigerian experience and structural causes (30th December, 2020). Retrieved from Central Bank of Nigeria: https://mpra.ub.unimuenchen.de/103131/MPRA Paper No. 103131.

[23] Poulos, C., Curran, D., Anastassopoulou, A., and De Moerlooze, L. (2018). German travellers' preferences for travel vaccines assessed by a discrete choice experiment. Vaccine, 36, (7), 969978.

[24] PricewaterhouseCoopers. (2018). As good as it gets? UK Hotels Forecast 2018. Retrieved August 11, 2018, from www.pwc.co.uk/hospitality-leisure.

[25] Robert, H. W., Jack, D. N., David, K. H and Michele, A. A. (2007). Professional Front Office Management. Upper Saddle River, New Jersey: Pearson Education INC.

[26] The Lagos Chamber of Commerce and Industry (LCCI). (2020). COVID-19: LCCI seeks support for hospitality sector to prevent job loss (31st December, 2020). Retrieved from https://www.pulse.ng/business/covid-19-lcci-seeks-support-forhospitality-sector-to-prevent-job-loss.

[27] The Voice of Africa. (2020). African News. Retrieved December 29th , 2020, from Africannews.com/tag/coronavirus.

[28] World Health Organisation. (2020). WHO Coronavirus Dieease (Covid 19) Dashboard. Retrieved 2020, from COVID19.WHO.IMT/region/amro/country/US.

[29] World Tourism Organization. (2016). UNWTO World Tourism Barometer. Retrieved from Madrid: UNWTO:http://www.unwto.org/facts/eng/barometer.htm.

[30] Wu, T., Perrings, C., Kinzig, A., Collins, J. P., Minteer, B. A., and Daszak, P. (2017). Economic growth, urbanization, globalization, and the risks of emerging infectious diseases in China: a review. Ambio, 46, (1), 18-29. 